\title{
MORPHOLOGICAL AND MOLECULAR CHARACTERIZATION OF LOCAL COMMON BEAN (PHASEOLUS VULGARIS L.) GENOTYPES
}

\author{
EKBIÇ, E. ${ }^{*}$ - HASANCAOĞLU, E. M. \\ Department of Horticulture, Agricultural Faculty, Ordu University, 52200 Ordu, Turkey \\ (phone: +90-452-226-5200/ext.:6238; fax: +90-452-234-6632) \\ *Corresponding author \\ e-mail: ercanekbic@gmail.com \\ (Received 26 $6^{\text {th }}$ Sep 2018; accepted 26 ${ }^{\text {th }}$ Nov 2018)
}

\begin{abstract}
This study was conducted for morphological and molecular characterization of 33 common bean genotypes collected from Ordu province in Turkey. Genetic relationships among the local common bean genotypes were also identified. In presented genotypes, 3 phenological and 22 morphological characteristics were investigated. The first flower and the first beans were formed 43.42 and 48.55 days after sowing time respectively. The first fresh bean harvest was realized 67.85 days after the sowing time. Pod lengths and pod widths of the genotypes varied between 10.93 and $23.23 \mathrm{~cm}$ (average $14.76 \mathrm{~cm}$ ) and 9.39-22.73 $\mathrm{mm}$ (average $15.22 \mathrm{~mm}$ ) respectively. The first 3 dimensions (PC1, PC2 and PC3) of principal component analysis on morphological data explained $72.27 \%$ of total variation. Seed main color, seed secondary color, pod color, pod cross-section and stringiness were prominent characteristics in screening of common bean genotypes. Of the SSR primers, SSR-IAC116 yielded the greatest PIC value (0.82) and it was followed by BMD-45-AIA (0.77) and PV ag004 (0.72) primers. The primers had a mean number of alleles per locus of 2.55. The BM210 had the greatest number of polymorphic alleles per locus ( 6 alleles). Cluster analysis, composed from molecular data, revealed 3 main groups. The genotypes G14 and G17 were placed alone in the first and second groups and the rest were clustered in the third group. The similarity index values among 33 local common bean genotypes varied between 0.34 and 0.97 . The genotypes G04 and G22 were identified as the closest genotypes with a genetic similarity coefficient of 0.97 .
\end{abstract}

Keywords: genetic resources, diversity, SSR, PCA, polymorphism

\section{Introduction}

Common bean (Phaseolus vulgaris L.) is an annual herbaceous vegetable and is a member of Phaseolus genus of legumes (Fabaceae) family. About $90 \%$ of culture common beans is constituted by Phaseolus vulgaris L. species of Phaseolus genus. There are two gene centers of beans as of Central America (Mesoamerica) and South America (Andean) (Gepts, 2008). There is no precise information about the entry time of the beans to Turkey. However, it is thought that beans entered from Europe to Anatolia 250-300 years ago (Eşiyok, 2012). Bean is produced as the main crop in several regions of Turkey and cultivated as the second crop especially in coastal regions. Ordu province is located in Central and Eastern Black Sea regions and fresh green beans are produced over 478 ha land area with an annual production of 2.870 tons (TÜIKK, 2017). Agricultural cultivation and biodiversity have been tightly associated for thousands years and it is still an ongoing process (Lockwood, 1999; Norris, 2008). Turkey with current geographical position and ecological conditions is an origin and diversity center of several plants. Such a diversity resulted from the history since Turkey is among the oldest civilizations. However, natural resource diversity and richness of Turkey is continuously decreasing because of some factors such as rapid 
increase in population, environmental pollution, widespread of newly released cultivars and natural disasters (Özgen et al., 1995). From such threating factors especially high cultivar dynamism in vegetable crops have led farmers to leave local cultivars and use hybrid cultivars instead (Bellon et al., 2015). To encourage the farmers for agroecologic, organic and sustainable farming is the most preservative approach for such a rich biodiversity (Altieri, 1999; Finegan and Nasi, 2004; Crowder et al., 2010). Plant genetic resources are composed of local genotypes, their wild relatives, old cultivars and lines with fully-identified genetic characteristics. Local genotypes (landraces) are populations generated through natural or artificial selections for years. Just as commercial cultivars, these populations are stable, high-yield and uniform populations with low adaptation capacities for the regions other than their origin (Zeven, 1998). Besides, biotic and abiotic stress tolerance and some nutritional quality treats of local genotypes are indispensable for plant breeders (Dwivedi et al., 2016). Therefore, preservation and appraisal of local genotypes are the issues of top priority (Negri et al., 2009). Genetic richness has a significant place in plant breeding. Thus, morphologic characterization and DNA-based definition of landraces or populations and put forth of relativeness degrees are significant issues in breeding studies. Due to landraces or local genotypes have a large genetic bases, such as resistance to pests and diseases and carrying genes related to several quality attributes, they constitute a significant gene source for preservation of the potential of the population they belonged to. Some genotypes even have significant quality attributes desired by the consumers and such consumers generally pay more for these products (Negri and Tosti, 2002; Galvan et al., 2006). Although common bean is originated from Central America, it is quite welladapted to ecological conditions of Black Sea region. The region has a quite large genetic variation since local farmers have been mixed-sowing the genotypes they used for years. Morphological differences are used to put forth such a broad diversity. Morphological characterization in essence is an evolutionary method basically focusing on traditional identification of evolutionary and pedigree relations. Using morphological measurements in diversity assessment for phenotypic and agronomic traits such as flower color, growth habit, yield potential, plant height, stress tolerance etc., have limitations, because such morphological traits are governed quantitatively and under environmental influence (Skroch and Nienhuis, 1995). However, the genetic analyses carried out with DNA markers are independent from environment effect. Such analyses are also more informative and quite available for characterization of genetic materials. For genetic characterization of common bean genotypes, restriction fragment length polymorphisms (RFLP) (Velasquez and Gepts, 1994), random amplified polymorphic DNA (RAPD) (Mavromatis et al., 2010; Bukhari et al., 2015), retrotransposon-based interprimer binding sites (iPBSs) (Nemli et al., 2015) and simple sequence repeated (SSR) (Yu et al., 2000; Gaitán-Solís et al., 2002; Blair et al., 2011; Khaidizar et al., 2012) marker techniques were used. Simple sequence repeated markers, also called as microsatellite, are commonly encountered in several loci of a genome (Tautz and Renz, 1984) and these markers were successfully used in genetic characterizations of the common beans (Gomez et al., 2005; Blair et al., 2006; Buso et al., 2006; Sarikamis et al., 2009; Khaidizar et al., 2012; Ulukap1 and Onus, 2013). This study was carried out to determine the genetic diversity between 33 local common bean genotypes collected from Ordu province by morphological and molecular characterization. Research findings were expected to have great contributions for definition of a common bean 
genetic pool of Ordu province, for preservation of local common bean genotypes and for further breeding studies to be carried out on common beans.

\section{Materials and methods}

As the material of the study, 33 bean genotypes collected from different towns of Ordu province in Turkey were used (Fig. 1; Table 1).

The seeds were sown in 14-liter pots containing 3:1 (v/v) peat:perlite mixture. Each pot had 3 plants, and 6 plants were used for observations for each genotype.

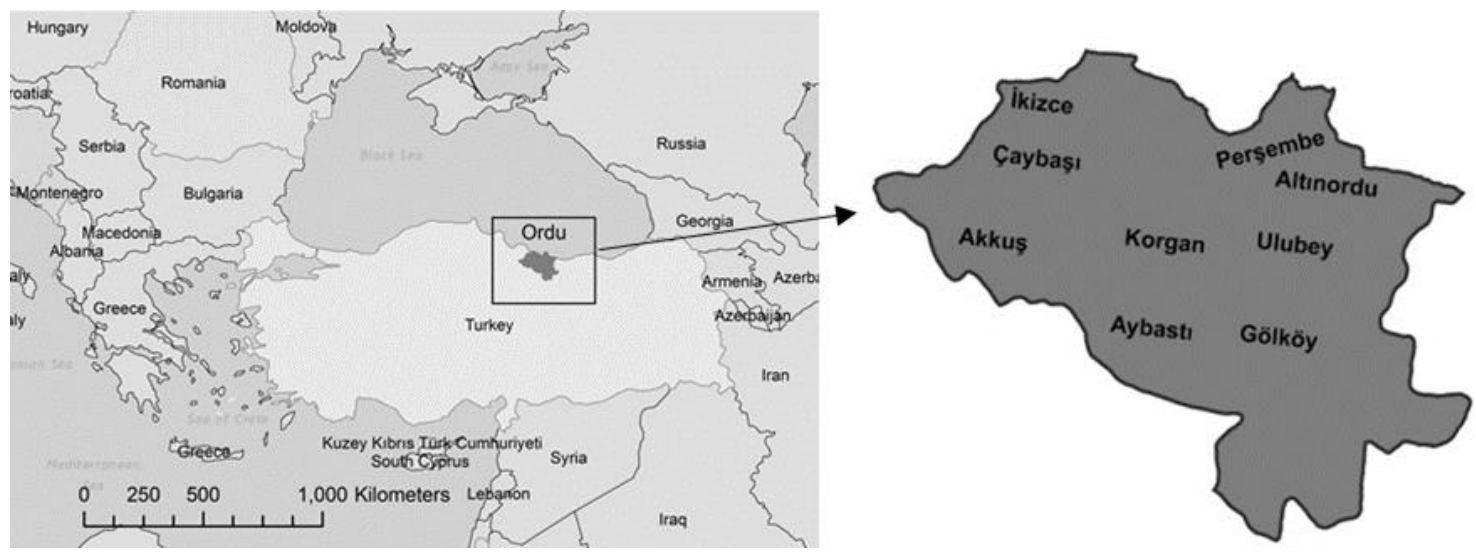

Figure 1. Location of the common bean genotypes sampling

Table 1. Coordinates of collected common bean genotypes

\begin{tabular}{l|c|c|c|c|c|c|c|c|c}
\hline Genotype & Location & $\begin{array}{c}\text { Latitude } \\
\text { (North) }\end{array}$ & $\begin{array}{c}\text { Longitude } \\
(\mathbf{E a s t})\end{array}$ & $\begin{array}{c}\text { Altitude } \\
(\mathbf{m})\end{array}$ & Genotype & Location & $\begin{array}{c}\text { Latitude } \\
\text { (North) }\end{array}$ & $\begin{array}{c}\text { Longitude } \\
\text { (East) }\end{array}$ & $\begin{array}{c}\text { Altitude } \\
(\mathbf{m})\end{array}$ \\
\hline $\mathbf{G 0 1}$ & Altınordu & $40.945^{\circ}$ & $37.916^{\circ}$ & 89 & $\mathbf{G 1 8}$ & Çaybaş1 & $41.029^{\circ}$ & $37.083^{\circ}$ & 523 \\
$\mathbf{G 0 2}$ & Altınordu & $40.945^{\circ}$ & $37.929^{\circ}$ & 50 & $\mathbf{G 1 9}$ & Çaybaş1 & $41.017^{\circ}$ & $37.080^{\circ}$ & 509 \\
$\mathbf{G 0 3}$ & Altınordu & $40.948^{\circ}$ & $37.917^{\circ}$ & 85 & $\mathbf{G 2 0}$ & Akkuş & $40.792^{\circ}$ & $37.007^{\circ}$ & 1243 \\
$\mathbf{G 0 4}$ & Altınordu & $40.937^{\circ}$ & $37.895^{\circ}$ & 68 & $\mathbf{G 2 1}$ & Akkuş & $40.793^{\circ}$ & $37.020^{\circ}$ & 1262 \\
$\mathbf{G 0 5}$ & Altınordu & $40.968^{\circ}$ & $37.858^{\circ}$ & 160 & $\mathbf{G 2 2}$ & Akkuş & $40.804^{\circ}$ & $37.037^{\circ}$ & 1223 \\
$\mathbf{G 0 6}$ & Altınordu & $40.965^{\circ}$ & $37.869^{\circ}$ & 106 & $\mathbf{G 2 3}$ & Akkuş & $40.713^{\circ}$ & $37.036^{\circ}$ & 951 \\
$\mathbf{G 0 7}$ & Altınordu & $40.957^{\circ}$ & $37.885^{\circ}$ & 83 & $\mathbf{G 2 4}$ & Akkuş & $40.709^{\circ}$ & $37.000^{\circ}$ & 1045 \\
$\mathbf{G 0 8}$ & Altınordu & $40.943^{\circ}$ & $37.882^{\circ}$ & 134 & $\mathbf{G 2 5}$ & Akkuş & $40.882^{\circ}$ & $37.066^{\circ}$ & 1122 \\
$\mathbf{G 0 9}$ & Perşembe & $41.055^{\circ}$ & $37.777^{\circ}$ & 13 & $\mathbf{G 2 6}$ & İkizce & $41.057^{\circ}$ & $37.086^{\circ}$ & 141 \\
$\mathbf{G 1 0}$ & Perşembe & $41.116^{\circ}$ & $37.759^{\circ}$ & 25 & $\mathbf{G 2 7}$ & Aybastı & $40.669^{\circ}$ & $37.423^{\circ}$ & 978 \\
$\mathbf{G 1 1}$ & Perşembe & $41.033^{\circ}$ & $37.788^{\circ}$ & 250 & $\mathbf{G 2 8}$ & Aybastı & $40.671^{\circ}$ & $37.413^{\circ}$ & 749 \\
$\mathbf{G 1 2}$ & Ulubey & $40.887^{\circ}$ & $37.785^{\circ}$ & 447 & $\mathbf{G 2 9}$ & Aybastı & $40.672^{\circ}$ & $37.397^{\circ}$ & 698 \\
$\mathbf{G 1 3}$ & Altınordu & $40.968^{\circ}$ & $37.959^{\circ}$ & 49 & $\mathbf{G 3 0}$ & Aybastı & $40.680^{\circ}$ & $37.428^{\circ}$ & 911 \\
$\mathbf{G 1 4}$ & Altınordu & $40.961^{\circ}$ & $37.967^{\circ}$ & 159 & $\mathbf{G 3 1}$ & Aybastı & $40.686^{\circ}$ & $37.446^{\circ}$ & 1048 \\
$\mathbf{G 1 5}$ & Gölköy & $40.749^{\circ}$ & $37.676^{\circ}$ & 796 & $\mathbf{G 3 2}$ & Aybastı & $40.714^{\circ}$ & $37.411^{\circ}$ & 775 \\
$\mathbf{G 1 6}$ & Korgan & $40.826^{\circ}$ & $37.335^{\circ}$ & 678 & $\mathbf{G 3 3}$ & Aybastı & $40.696^{\circ}$ & $37.399^{\circ}$ & 802 \\
$\mathbf{G 1 7}$ & Çaybaş1 & $41.034^{\circ}$ & $37.104^{\circ}$ & 289 & & & & & \\
\hline
\end{tabular}




\section{Morphological observations}

Local common bean genotypes were evaluated for the time elapsed from sowing time to the first bloom (Flo, day), the first pod formation time (PF, day), the first fresh bean harvest time (GPH, day), pod length (PL, cm), pod width (PW, mm), leaf length (LL, cm), leaf width (LW, cm), terminal leaflet length (TLL, cm), terminal leaflet width (TLW), leaf color (LC), seed length (SL, mm), seed width (SWi, mm), 100 seed weight (SWe, g), pod cross-section (PCS), pod roughness (PR), stringiness (S), shape of distal part (beak, B), pod color (PC), pod secondary color (PSC), pod curvature level (PCL), seed clarity (SC), main seed color (MSC), secondary seed color (SSC) and distribution of secondary color on the seed (DSSC) characteristics in accordance with the standards specified in Genchev and Kiryakov (2005).

\section{Molecular characterization}

The BM146, BM210, Bmd-45-AIA, Bmd-8, DROUGH1, PH10B11, PH7B3, PV aaat001, PV ag004, PV at007, PV at008, PV atcc001, PV atcc003, PV atct001, PV gaaat001, SSR-IAC26, SSR-IAC63 and SSR-IAC116 primers selected among the ones used by Ulukap1 and Onus (2013) were used for molecular characterization of present common bean genotypes. DNA isolation was performed by using CTAB (cetyl trimethyl ammonium bromide) method in accordance with the protocol of Haymes (1996). DNA concentrations were diluted with TE solution (10 mM Tris, $1 \mathrm{mM}$ EDTA, $\mathrm{pH}$ 8.0) to $5 \mathrm{ng} / \mu \mathrm{l}$. PCR reactions were performed in LongGene A300 Fast thermal cycler in a total volume of $15 \mu \mathrm{l}$ generated through addition of $7.5 \mu$ l PCR Master Mix (Dreamtaq Green Master Mix $), 1 \mu l$ forward primer $(10 \mathrm{pmol}), 1 \mu \mathrm{l}$ reverse primer $(10 \mathrm{pmol})$, $2.5 \mu 1 \mathrm{ddH}_{2} \mathrm{O}$ and $3 \mu \mathrm{l}$ DNA. PCR amplifications were performed in accordance with the protocol of Khaidizar et al., (2012). Amplification conditions were set as; predenaturation at $94{ }^{\circ} \mathrm{C}$ for $3 \mathrm{~min}, 2$ cycles at $94^{\circ} \mathrm{C}$ for $30 \mathrm{~s}$, at $37{ }^{\circ} \mathrm{C}$ for $60 \mathrm{~s}$, at $72^{\circ} \mathrm{C}$ for $2 \mathrm{~min}, 2$ cycles at $94^{\circ} \mathrm{C}$ for $30 \mathrm{~s}$, at $50{ }^{\circ} \mathrm{C}$ for $60 \mathrm{~s}$, at $72^{\circ} \mathrm{C}$ for $2 \mathrm{~min}, 41$ cycles at $93{ }^{\circ} \mathrm{C}$ for $30 \mathrm{~s}$, at $50{ }^{\circ} \mathrm{C}$ for $60 \mathrm{~s}$, at $72{ }^{\circ} \mathrm{C}$ for $2 \mathrm{~min}$ and finally at $72{ }^{\circ} \mathrm{C}$ for $5 \mathrm{~min}$. Resultant SSR-PCR products were run in 3\% agarose (Fisher BioReagents) gel containing 1x TAE (Tris-Acetic acid-EDTA) solution in SCIE-PLAS (Hu20) electrophoresis unit. Electrophoresis process was performed at 90 Watt and $300 \mathrm{~mA}$ current rates for 4 hours. Agarose gel was stained with ethidium bromide $(10 \mathrm{mg} / \mathrm{ml})$ for $20 \mathrm{~min}$ and imaged under UV transilluminator (Syngene-Ingenius). Bands in resultant gel images were scored as 1 (present) and 0 (absent) and binary data matrices were generated for data analyses.

\section{Statistical analysis}

Descriptive statistics for morphological data were calculated with SPSS v.22.0 statistical software, principal component analysis for qualitative phenotypic data was performed with the aid of Past3 software. Polymorphism information content (PIC) values of SSR primers were calculated with the aid of the following modified by Anderson et al. (1993):

$$
P I C_{i}=1-\sum_{j=1}^{n} P i j^{2}
$$


where pij is the frequency of the $\mathrm{j}^{\text {th }}$ allele for marker $\mathrm{i}$ and summation extends over $\mathrm{n}$ alleles. Molecular data were analyzed via Dice module of NTSYSpc v.2.02 (Rolf, 2000) software. Cluster analysis was performed by using UPGMA (un-weighted pair group method with arithmetic mean) (Sneath and Sokal, 1973) and a correlation matrix was generated then.

\section{Results and discussion}

\section{Morphological characterization of bean genotypes}

With regard to type of growth, $93.93 \%$ of the genotypes were climbing type (31 genotypes) and 6.07\% showed dwarf growing habit (G09, G24). Sözen et al. (2014) carried out a study with 85 bean genotypes and identified 12 genotypes (14.1\%) as dwarf, 42 genotypes (49.4\%) as semi-dwarf and 31 genotypes (36.5\%) as climbing type. Descriptive statistics for quantitative pod and leaf characteristics and phenological observations of the local bean genotypes are provided in Table 2. Mean flowering time of the local genotypes apart from the sowing time was 43.42 days. The earliest flowering was observed in in G09, G15, G21, G26 and G27 genotypes with 41 days and the latest flowering was observed in G07 with 55 days. The earliest genotype formed the first pod in 46 days and the latest genotypes formed the first pod in 59 days. Mean the first pod formation time was 48.55 days. The first fresh pod harvest was performed in 58 days in early genotypes (G01, G24, G26, G27 and G32) and in 85 days in late genotype (G07). Pod lengths varied between 10.93 and $23.23 \mathrm{~cm}$. The shortest pod was observed in G09 genotype with $10.93 \mathrm{~cm}$ and the longest pod was observed in G33 genotype with $23.23 \mathrm{~cm}$. Pod widths varied between 9.39 and $22.73 \mathrm{~mm}$. The lowest pod width value was obtained in G14 genotype with $9.39 \mathrm{~cm}$ and the largest pod was obtained in G25 genotype with $22.73 \mathrm{~cm}$ as was seen in Table 2. Variation coefficients for tip leaf length, tip leaf width, side leaf length and side leaf width were respectively calculated as 15.67, 13.93, 14.49 and $13.43 \%$. Kar et al. (2005) assessed earliness, yield and quality attributes of 4 determinate and 5 pole-type bean cultivars under unheated greenhouse conditions. Researchers reported the earliest flowering time as 58 days for determinate cultivars and 59 days for pole-type cultivars and reported the first pod harvest times as between 63 and 68 days. Erdinç et al. (2013) reported the earliest flowering time as 42 days, the latest flowering time as 77 days, the first pod harvest time as 68 days and the latest pod harvest time as 127 days in different common bean genotypes. In another genetic characterization study carried out with 300 common bean genotypes in Honduras, the first flowering times were reported as between 31 and 37 days (Meza et al., 2013). Akbulut et al. (2013) carried out s study with 12 bean genotypes grown in Burdur province and reported the first pod formation time as between 46 and 68 days. In similar previous studies carried out with common beans in Turkey, pod lengths were reported as between 7.48 and $13.8 \mathrm{~cm}$ and pod widths as between 7 and $25 \mathrm{~mm}$ (Düzdemir, 1998; Madakbaş et al., 2004).

Seed characteristics evaluations of local bean genotypes are provided in Table 3. 100 seed weights varied between 29.67 and $66.40 \mathrm{~g}$. The lowest seed weight value was observed in G14 and the highest seed weight value was obtained from G06 genotype. The greatest variation was observed in seed thickness $(16.91 \%)$ and it was followed by seed weight (14.85), seed length (9.56\%) and seed width (7.62\%). Piergiovanni et al. (2006) reported that seed variation of the common bean germplasm in Abruzzo and Lazio (Italy) was low and 100-seed weight varied between 32.9 and $91.4 \mathrm{~g}$. 
Table 2. Descriptive statistics data obtained from some plant growing and leaf characteristics

\begin{tabular}{c|c|c|c|c|c|c|c|c|c}
\hline & $\begin{array}{c}\text { Flo } \\
(\mathbf{d a y})\end{array}$ & $\begin{array}{c}\text { PF } \\
(\mathbf{d a y})\end{array}$ & $\begin{array}{c}\text { GPH } \\
(\mathbf{d a y})\end{array}$ & $\begin{array}{c}\text { PL } \\
(\mathbf{c m})\end{array}$ & $\begin{array}{c}\text { PW } \\
(\mathbf{m m})\end{array}$ & $\begin{array}{c}\text { TLL } \\
(\mathbf{c m})\end{array}$ & $\begin{array}{c}\text { TLW } \\
(\mathbf{c m})\end{array}$ & $\begin{array}{c}\text { LL } \\
(\mathbf{c m})\end{array}$ & $\begin{array}{c}\text { LW } \\
(\mathbf{c m})\end{array}$ \\
\hline Mean & 43.42 & 48.55 & 67.85 & 14.76 & 15.22 & 14.88 & 10.89 & 14.05 & 10.24 \\
Minimum & 41.00 & 46.00 & 58.00 & 10.93 & 9.39 & 10.71 & 8.53 & 10.91 & 8.04 \\
Maximum & 55.00 & 59.00 & 85.00 & 23.23 & 22.73 & 23.77 & 17.75 & 21.48 & 16.25 \\
Std. dev. & 2.93 & 2.59 & 6.01 & 2.88 & 2.98 & 2.33 & 1.52 & 2.04 & 1.37 \\
CV \% & 6.74 & 5.33 & 8.85 & 19.54 & 19.55 & 15.67 & 13.93 & 14.49 & 13.43 \\
\hline
\end{tabular}

Std. dev.: standard deviation; CV: coefficient of variation

Table 3. Descriptive statistics data obtained from the seed characteristics

\begin{tabular}{c|c|c|c|c}
\hline & 100 SWe $(\mathbf{g})$ & SL $(\mathbf{m m})$ & SWi $(\mathbf{m m})$ & ST $(\mathbf{m m})$ \\
\hline Mean & 49.07 & 14.09 & 8.21 & 6.52 \\
Minimum & 29.67 & 11.70 & 6.22 & 5.04 \\
Maximum & 66.40 & 16.28 & 9.30 & 10.42 \\
Std. dev. & 2.19 & 1.34 & 0.62 & 1.10 \\
CV \% & 14.88 & 9.56 & 7.62 & 16.91 \\
\hline
\end{tabular}

Std. dev.: standard deviation; CV: coefficient of variation

\section{Principal component analysis (PCA)}

Results of principal component analysis for 12 qualitative characteristics of bean genotypes are provided in Table 4. PC 1 (41.97\%), PC $2(21.37 \%)$ and PC $3(8.93 \%)$ axes explained $72.27 \%$ of total variation among the genotypes. On PC 1 axis, seed main color with a variation coefficient of 0.95 was the primary attribute, the most distinctively indicating the variation among the genotypes. On PC 2 axis, pod secondary color $(0.80)$ and seed secondary color $(0.75)$ were the most distinctive characteristics. On PC 3 axis, pod cross-section (0.82) and stringiness (0.61) were the most distinctive characteristics effecting the variation among the genotypes. Lima et al. (2012) reported that first two principle components explained about $34 \%$ of the total variation on common bean genotypes. Meza et al. (2013) indicated that first tree principle components explained $34.18 \%$ of total variation and reported the first flowering time, ripened pod color and pod harvest time as the most distinctive characteristics.

\section{Molecular characterization}

The 18 SSR markers used in molecular characterizations generated a total of 63 alleles and 46 of them (73\%) were polymorphic among the common bean genotypes. Number of alleles per locus varied between 2 and 6 (average 2.55 alleles per locus) (Fig. 2). While PBM210, PV aaat001 and PV ag004 SSR primers yielded the greatest number of alleles per locus, the greatest number of polymorphic alleles per locus (6 alleles) was observed in BM210 primer. Polymorphism information content (PIC) of the primers varied between 0.06 and 0.82 (Fig. 3). The greatest PIC value (0.82) was obtained from SSR-IAC116 primer. 
Table 4. Eigenvectors of the first three dimensions of PCA

\begin{tabular}{c|c|c|c}
\hline Characters & PC 1 & PC 2 & PC 3 \\
\hline Pod cross section & -0.06 & 0.11 & $\mathbf{0 . 8 2}$ \\
Pod roughness & -0.32 & 0.57 & 0.10 \\
Stringiness & 0.22 & 0.25 & $\mathbf{0 . 6 1}$ \\
Shape of distal part (beak) & -0.03 & -0.26 & -0.38 \\
Pod color & -0.31 & -0.02 & 0.22 \\
Pod secondary color & -0.34 & $\mathbf{0 . 8 0}$ & -0.03 \\
Pod degree of curvature & 0.26 & -0.11 & 0.49 \\
Seed clarity in pods & -0.27 & 0.27 & 0.06 \\
Leaf color & -0.27 & 0.06 & 0.23 \\
Seed main color & $\mathbf{0 . 9 5}$ & 0.30 & -0.03 \\
Seed secondary color & -0.55 & $\mathbf{0 . 7 5}$ & -0.08 \\
Distribution of seed secondary color & -0.57 & 0.54 & -0.11 \\
\hline Individual variance \% & $\mathbf{4 1 . 9 7}$ & $\mathbf{2 1 . 3 7}$ & $\mathbf{8 . 9 3}$ \\
\hline Cumulative variance (PC1 + PC2 + PC3): 72.27\% & &
\end{tabular}

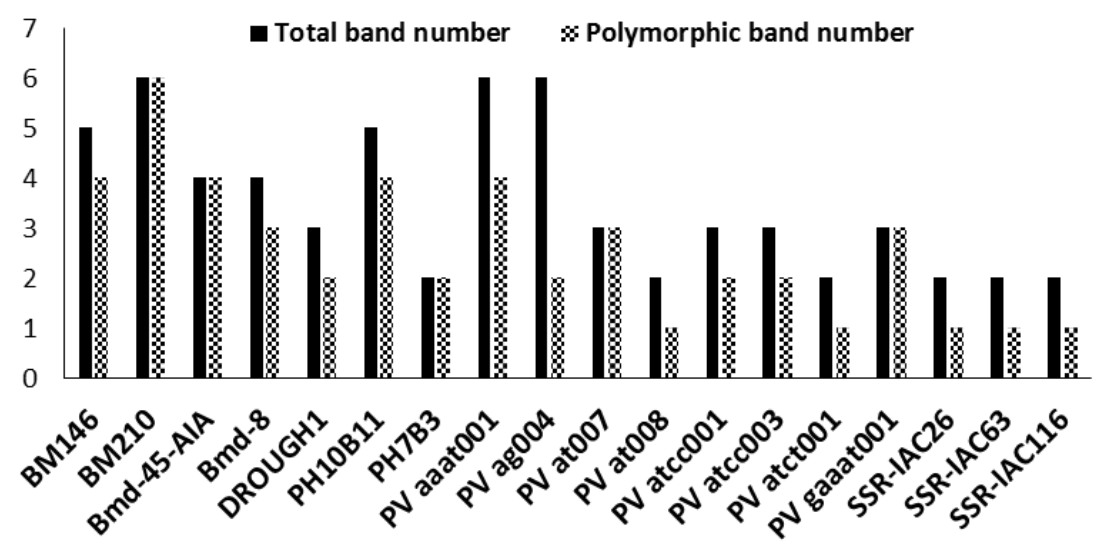

Figure 2. Total number and polymorphic band numbers revealed by SSR primers in common bean genotypes

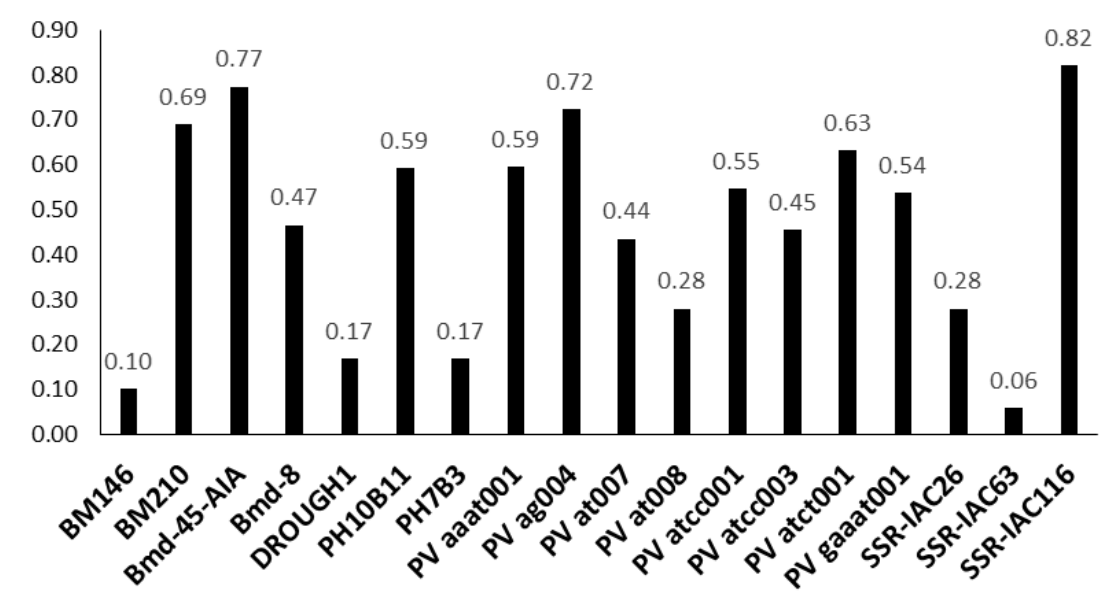

Figure 3. Polymorphism information content of SSR primers in common bean genotypes 
Lioli et al. (2005) carried out a diversification study with 33 local common bean genotypes using 14 SSR primers and reported number of alleles per locus as between 2 and 11. Sarıkamıs et al. (2009) used 12 SSR primers in a genetic diversity study for 30 common bean genotypes and identified 10 SSR primers as polymorphic. Researchers obtained 45 polymorphic alleles from 10 SSR primers and reported number of alleles per locus as between 2 and 10. Khaidizar et al. (2012) identified bean genotypes collected from Northern Anatolia with the aid of 30 SSR primers and obtained 72 alleles from these SSR primers. Ulukap1 and Onus (2013) indicated 73\% polymorphism ratio for 22 SSR primers and reported PIC values as between 0.047 and 0.373 . Buah vet al. (2017) used 6 SSR primers for bean genotypes and obtained 41 alleles (average 7.8 alleles per locus). De Luca et al. (2018) used microsatellite markers for Italian local bean genotypes and reported PIC values as between 0.315 and 0.928 .

\section{Genetic relationships between local common bean genotypes}

Results obtained from PCR reactions revealed that similarity index among bean genotypes varied between 0.34 and 0.97 (Table 5). A dendrogram was generated with SSR primers (Fig. 4) and bean genotypes were separated into 3 main groups in this dendrogram.

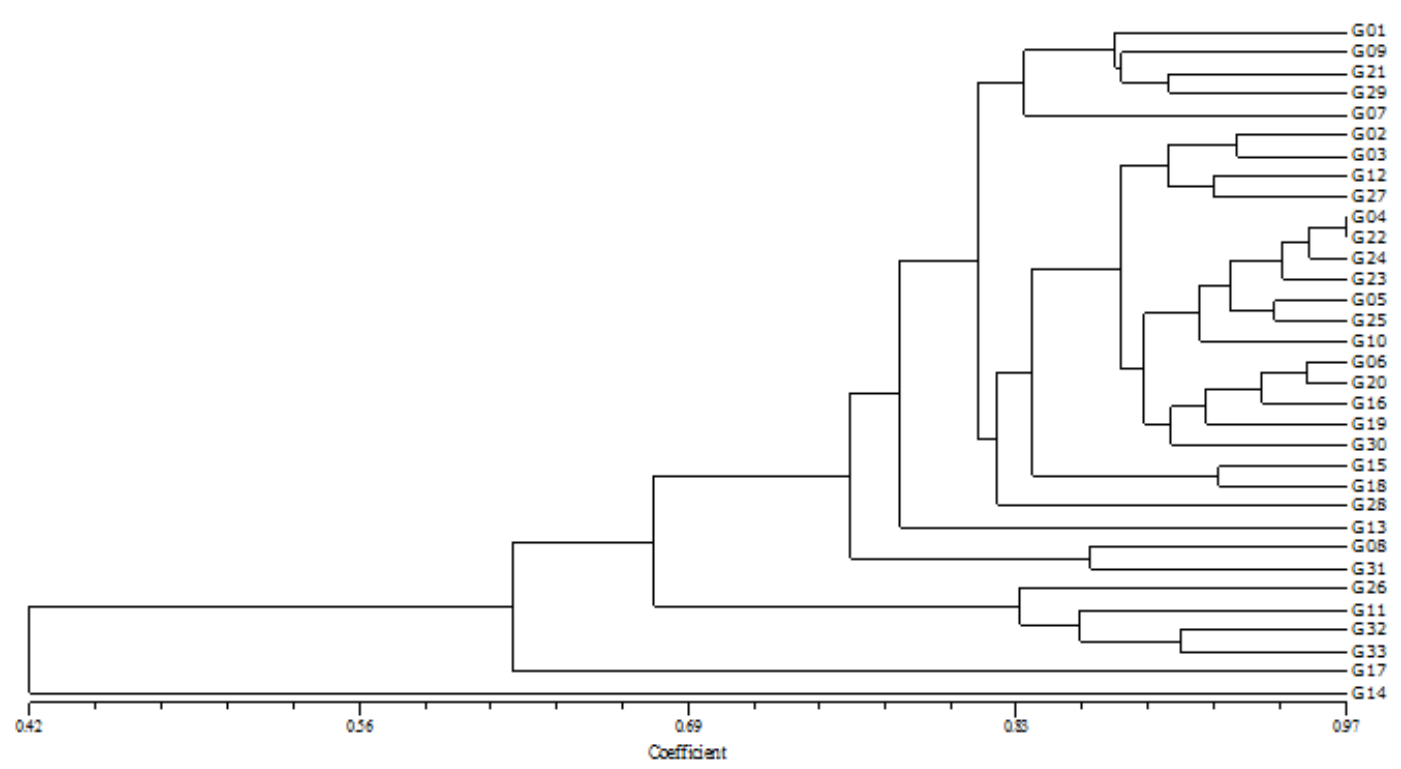

Figure 4. UPGMA dendrogram based on SSR markers

The genotype G14 collected from Altınordu town of Ordu and the genotype G17 collected from Çaybaşı town of Ordu were alone placed in the first and second group of the dendrogram. The difference of G14 and G17 genotypes were also quite distinctive in principal coordinate scatter plot (Fig. 5). All the other genotypes were clustered in the third group. The genotypes G04 and G22 collected from Altınordu and Akkuş towns of Ordu province were the closest genotypes with a genetic similarity index of 0.97 . Cluster analysis did not yield town-based geographical separation of the genotypes. Such a case was because local bean producers generally produce their own seeds and 
seeds of a locality are served to different local markets. Khaidizar et al. (2012) reported genetic similarity coefficient between the bean genotypes collected from Erzurum and Bayburt provinces as between 0.211 and 0.796 and gathered bean genotypes under two main groups. Ulukap1 and Onus (2013) used SSR primers for characterization of 39 bean genotypes and reported genetic similarity coefficients as between 0.52 and 0.98 . Researchers gathered bean genotypes under two main groups of a dendrogram. Bukhari et al. (2015) carried out a characterization study with 45 bean genotypes and separated bean genotypes into 7 main groups and reported genetic similarity coefficients as between 0.56 and 0.92 .

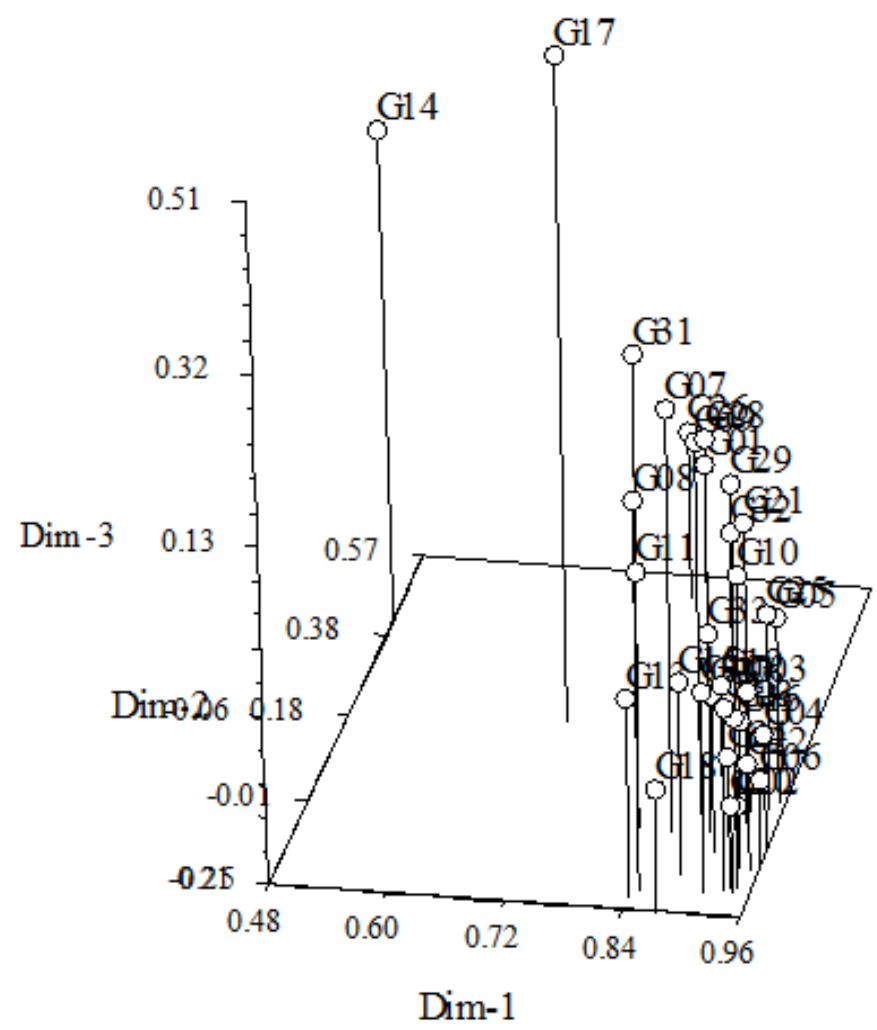

Figure 5. Scatterplot illustration drawn using SSR data

\section{Conclusion}

Genetic variations in a gene pool constitute basic sources for breeders. Hereditary characteristics of the materials in this genetic pool should be identified with proper methods and genetic relations among them should be put forth. Such efforts play a significant role in meeting farmer needs. Present local common been genotypes grown in Central Black Sea region exhibited differences in seed color, pod color and pod stringiness. Molecular characterizations by SSR markers used in this study did not revealed distinctive groups or geographical separations with regard to morphological characteristics. Bean genotypes of Ordu province had a genetic similarity of between 34 and $97 \%$. Such a broad genetic variation may have significant contributions in developing new common bean cultivars.

Acknowledgements. This study was financed by Ordu University with Project Code: TF1438. 
Table 5. Genetic similarity matrix between 33 common bean local accessions based on SSR markers

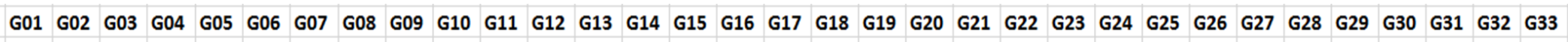
G01 1.00

G02 0.821 .00

G03 0.800 .931 .00

G04 $0.770 .900 .91 \quad 1.00$

$\begin{array}{lllllll}G 05 & 0.82 & 0.88 & 0.90 & 0.96 & 1.00\end{array}$

\begin{tabular}{ll|l|l|l|l|l} 
G06 & 0.83 & 0.93 & 0.91 & 0.94 & 0.93 & 1.00
\end{tabular}

\begin{tabular}{ll|l|l|l|l|l|l} 
G07 & 0.85 & 0.75 & 0.79 & 0.77 & 0.81 & 0.79 & 1.00
\end{tabular}

$\begin{array}{lllllllllll}\mathbf{G} 08 & 0.78 & 0.75 & 0.76 & 0.77 & 0.75 & 0.84 & 0.81 & 1.00\end{array}$

$\begin{array}{llllllllllll}\text { G09 } & 0.87 & 0.79 & 0.75 & 0.81 & 0.84 & 0.80 & 0.87 & 0.72 & 1.00\end{array}$

$\begin{array}{lllllllllllll}\text { G10 } & 0.82 & 0.83 & 0.87 & 0.94 & 0.92 & 0.90 & 0.81 & 0.81 & 0.86 & 1.00\end{array}$

\begin{tabular}{l|l|l|l|l|l|l|l|l|l|l|l|l} 
G11 & 0.62 & 0.66 & 0.69 & 0.64 & 0.68 & 0.67 & 0.59 & 0.54 & 0.57 & 0.59 & 1.00
\end{tabular}

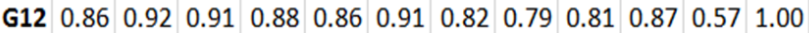

\begin{tabular}{llllll|l|l|l|l|l|l|l|l|l|l|l} 
G13 & 0.73 & 0.79 & 0.81 & 0.81 & 0.76 & 0.84 & 0.72 & 0.71 & 0.72 & 0.79 & 0.49 & 0.86 & 1.00
\end{tabular}

\begin{tabular}{llllll|lllllllllll} 
G14 & 0.43 & 0.41 & 0.42 & 0.40 & 0.45 & 0.37 & 0.34 & 0.36 & 0.37 & 0.40 & 0.43 & 0.44 & 0.40 & 1.00
\end{tabular}

$\begin{array}{lllllllllllllllllll}\text { G15 } & 0.75 & 0.85 & 0.80 & 0.87 & 0.85 & 0.80 & 0.74 & 0.74 & 0.77 & 0.84 & 0.58 & 0.86 & 0.70 & 0.43 & 1.00\end{array}$

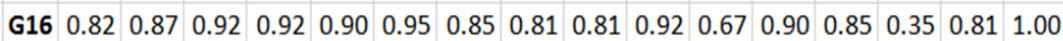

$\begin{array}{lllllllllllllllllllll}\text { G17 } & 0.67 & 0.57 & 0.67 & 0.64 & 0.69 & 0.58 & 0.73 & 0.62 & 0.70 & 0.68 & 0.48 & 0.61 & 0.59 & 0.44 & 0.58 & 0.64 & 1.00\end{array}$

$\begin{array}{lllllllllllllllllllllll}\text { G18 } & 0.68 & 0.83 & 0.77 & 0.88 & 0.83 & 0.84 & 0.67 & 0.75 & 0.70 & 0.81 & 0.54 & 0.83 & 0.74 & 0.41 & 0.92 & 0.81 & 0.49 & 1.00\end{array}$

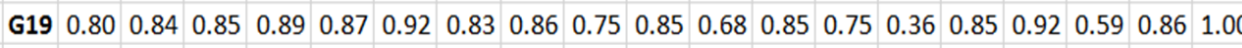

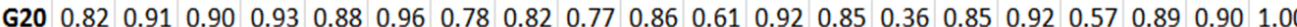

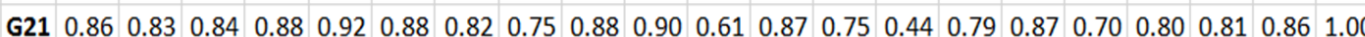

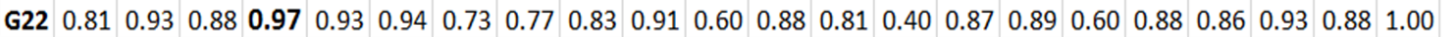

$\begin{array}{lllllllllllllllllllllllllllllll}\text { G23 } & 0.78 & 0.88 & 0.86 & 0.96 & 0.91 & 0.92 & 0.74 & 0.81 & 0.80 & 0.94 & 0.60 & 0.89 & 0.82 & 0.43 & 0.88 & 0.89 & 0.60 & 0.89 & 0.85 & 0.91 & 0.86 & 0.96 & 1.00\end{array}$

$\begin{array}{llllllllllllllllllllllllllll}\text { G24 } & 0.80 & 0.93 & 0.85 & 0.94 & 0.90 & 0.91 & 0.72 & 0.76 & 0.82 & 0.87 & 0.55 & 0.91 & 0.79 & 0.42 & 0.89 & 0.87 & 0.58 & 0.90 & 0.85 & 0.93 & 0.88 & 0.97 & 0.92 & 1.00\end{array}$

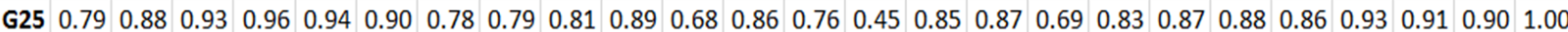

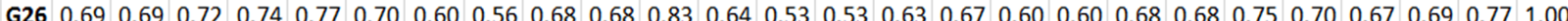

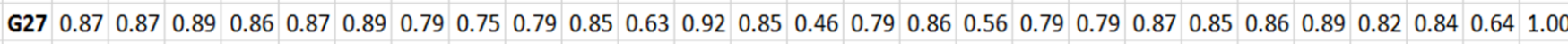

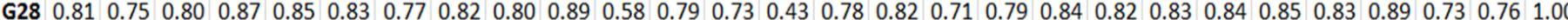

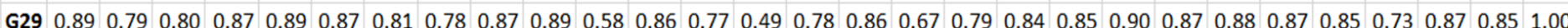

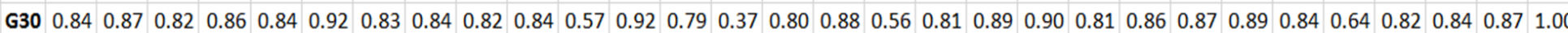

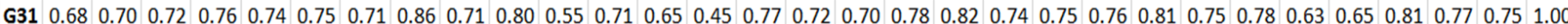

G32 $\begin{array}{llllllllllllllllllllllllllllllllllll} & 0.78 & 0.75 & 0.79 & 0.82 & 0.79 & 0.64 & 0.61 & 0.74 & 0.74 & 0.85 & 0.71 & 0.62 & 0.50 & 0.67 & 0.71 & 0.61 & 0.67 & 0.71 & 0.74 & 0.80 & 0.78 & 0.76 & 0.75 & 0.79 & 0.87 & 0.71 & 0.72 & 0.75 & 0.71 & 0.67 & 1.00\end{array}$

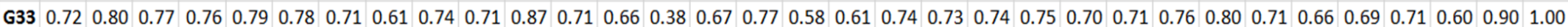

APPLIED ECOLOGY AND ENVIRONMENTAL RESEARCH 17(1): 841-853

http://www.aloki.hu • ISSN 15891623 (Print) • ISSN 17850037 (Online)

DOI: http://dx doi

(c) 2019, ALÖKI Kft., Budapest, Hungary 


\section{REFERENCES}

[1] Akbulut, B., Karakurt, Y., Tonguç, M. (2013): Fasulye (Phaseolus vulgaris L.) genotiplerinin moleküler karakterizasyonu. - Mediterranean Agricultural Sciences 26(2): 105-108.

[2] Altieri, M. A. (1999): The ecological role of biodiversity in agroecosystems. Agriculture, Ecosystems and Environment 74(1-3): 19-31.

[3] Anderson, J. A., Churchill, G., Autrique, J., Tanksley, S., Sorrells, M. (1993): Optimizing parental selection for genetic linkage maps. - Genome 36(1): 181-186.

[4] Bellon, M. R., Gotor, E., Caracciolo, F. (2015): Conserving landraces and improving livelihoods: how to assess the success of on-farm conservation projects? - International Journal of Agricultural Sustainability 13: 167-182.

[5] Blair, M. W., Hurtado, N., Chavarro, C. M., Muñoz-Torres, M. C., Giraldo, M. C., Pedraza, F., Tomkins, J., Wing, R. (2011): Gene-based SSR markers for common bean (Phaseolus vulgaris L.) derived from root and leaf tissue ESTs: an integration of the BMc series. - BMC Plant Biology 11: 50.

[6] Blair, M. W., Giraldo, M. C., Buendia, H. F., Tovar, E., Duque, M. C., Beebe, S. E. (2006): Microsatellite marker diversity in common bean (Phaseolus vulgaris L.). Theoretical Applied and Genetics 113: 100-109.

[7] Buah, S., Buruchara, R., Okori, P. (2017): Molecular characterisation of common bean (Phaseolus vulgaris L.) accessions from Southwestern Uganda reveal high levels of genetic diversity. - Genetic Resources and Crop Evolution 64(8): 1985-1998.

[8] Bukhari, A., Bhat, M., Ahmad, M., Saleem, N. (2015): Examination of genetic diversity in common bean (Phaseolus vulgaris L.) using random amplified polymorphic DNA (RAPD) markers. - African Journal of Biotechnology 14(6): 451-458.

[9] Buso, G. S. C., Amaral, Z. P. S., Brondani, R. P. V., Ferreira, M. E. (2006): Primer note: microsatellite markers for the common bean Phaseolus vulgaris. - Molecular Ecology Notes 6: 252-254.

[10] Crowder, D. W., Northfield, T. D., Strand, M. R., Snyder, W. E. (2010): Organic agriculture promotes evenness and natural pest control. - Nature 466(7302): 109-112.

[11] De Luca, D., Cennamo, P., Del Guacchio, E., Di Novella, R., Caputo, P. (2018): Conservation and genetic characterisation of common bean landraces from Cilento region (southern Italy): high differentiation in spite of low genetic diversity. - Genetica 146(1): $29-44$.

[12] Düzdemir, O. (1998): Kuru Fasulye (Phaseolus vulgaris L.) Genotiplerinde Verim ve Diğer Bazı Özellikler Üzerine Bir Araştırma. Yüksek Lisans Tezi, - GOÜ. Fen Bilimleri Enstitüsü, Tokat.

[13] Dwiedi, S. L., Ceccarelli, S., Blair, M. W., Upadhyaya, H. D., Are, A. K., Ortiz, R. (2016): Landrace germplasm for improving yield and abiotic stress adaptation. - Trends in Plant Science 21(1): 31-42.

[14] Erdinç, Ç., Türkmen, Ö., Şensoy, S. (2013): Türkiye'nin bazı fasulye genotiplerinin çeşitli bitkisel özelliklerinin belirlenmesi. - Yüzüncü Yıl Üniversitesi Tarım Bilimleri Dergisi 23(2): 112-125.

[15] Eşiyok, D. (2012): Kışlık ve Yazlık Sebze Yeiştiriciliği. - Meta Basım Matbaacılık Hizmetleri, İzmir.

[16] Finegan, B., Nasi, R. (2004): The Biodiversity and Conservation Potential of Shifting Cultivation Landscapes. Agroforestry and Biodiversity Conservation in Tropical Landscapes. - Island Press, Washington, DC, pp. 153-197.

[17] Gaitán-Solís, E., Duque, M., Edwards, K., Tohme, J. (2002): Microsatellite repeats in common bean (Phaseolus vulgaris). - Crop Science 42(6): 2128-2136.

[18] Galvan, M., Menendez-Sevillano, M., De Ron, A., Santalla, M., Balatti, P. A. (2006): Genetic diversity among wild common beans from northwestern Argentina based on 
morpho-agronomic and RAPD data. - Genetic Resources and Crop Evolution 53(5): 891900.

[19] Genchev, D., Kiryakov, I. (2005): Color Scales for Identification Characters of Common Bean (Phaseolus vulgaris L.). - Dobroudja Agricultural Institute-General, Toshevo.

[20] Gepts, P. (2008): Tropical Environments, Biodiversity, and the Origin of Crops. - In: Moonre, P., Ming, R. (eds.) Genomics of Tropical Crop Plants, Springer, New York, pp: $1-20$.

[21] Gomez, O. J., Blair, M. W., Frankow-Lindberg, B. E., Gullberg, U. (2005): Comparative study of common bean (Phaseolus vulgaris L.) landraces conserved ex situ in genebanks and in situ by farmers. - Genetic Resources and Crop Evolution 52: 371-380.

[22] Haymes, K. M. (1996): Mini-prep method suitable for a plant breeding program. - Plant Molecular Biology Reporter 14(3): 280-284.

[23] Kar, H., Balkaya, A., Apaydın, A. (2005): Samsun ekolojik koşullarında ilk turfanda taze fasulye yetiştiriciliğinde bazı çeşitlerin performanslarının belirlenmesi üzerinde bir araștırma. - GOÜ Ziraat Fakültesi Dergisi 22(1): 1-7.

[24] Khaidizar, M. I., Haliloglu, K., Elkoca, E., Aydin, M., Kantar, F. (2012): Genetic diversity of common bean (Phaseolus vulgaris L.) landraces grown in northeast Anatolia of Turkey assessed with simple sequence repeat markers. - Turkish Journal of Field Crops 17(2): 145-150.

[25] Lima, M. S., Carneiro, J. E. S., Carneiro, P. C. S., Pereira, C. S., Vieira, R. F. Cecon, P. R. (2012): Characterization of genetic variability among common bean genotypes by morphological descriptors. - Crop Breeding and Applied Biotechnology 12(1): 76-84.

[26] Lockwood, J. A. (1999); Agriculture and biodiversity: Finding our place in this world. Agriculture and Human Values 16: 365-379.

[27] Madakbaş, S. Y., Kar, H., Küçükomuzlu, B. (2004): Çarşamba Ovası'nda Bazı Bodur Taze Fasulye Çeşitlerinin Verimliliklerinin Belirlenmesi. - GOÜ Ziraat Fakültesi Dergisi 21(2): 1-6.

[28] Mavromatis, A., Arvanitoyannis, S., Korkovelos, A., Giakountis, A., Chatzitheodorou, V., Goulas, C. (2010): Genetic diversity among common bean (Phaseolus vulgaris L.) Greek landraces and commercial cultivars: nutritional components, RAPD and morphological markers. - Spanish Journal of Agricultural Research (4): 986-994.

[29] Meza, N., Rosas, J. C., Martín, J. P., Ortiz, J. M. (2013): Biodiversity of common bean (Phaseolus vulgaris L.) in Honduras. evidenced by morphological characterization. Genetic Resources and Crop Evolution 60(4): 1329-1336.

[30] Negri, V., Maxted, N., Vetelainen, M. (2009): European Landrace Conservation: An Introduction. - In: Vetelainen, M., Negri, V., Maxted, N. (eds.) European Landraces: OnFarm Conservation, Management and Use. ECP GR,Rome, Italy.

[31] Negri, V., Tosti, N. (2002): Phaseolus genetic diversity maintained on-farm in central Italy. - Genetic Resources and Crop Evolution 49(5): 511-520.

[32] Nemli, S., Kianoosh, T., Tanyolac, M. B. (2015): Genetic diversity and population structure of common bean (Phaseolus vulgaris L.) accessions through retrotransposonbased interprimer binding sites (iPBSs) markers. - Turkish Journal of Agriculture and Forestry 39(6): 940-948.

[33] Norris, K. (2008): Agriculture and biodiversity conservation: opportunity knocks. Conservation Letters 1(1): 2-11.

[34] Özgen, M., Adak, M., Karagöz, A., Ulukan, H. (1995): Bitkisel Gen Kaynaklarının Koruma ve Kullanımı. - Türkiye Ziraat Mühendisliği IV Teknik Kongresi 1: 309-344.

[35] Piergiovanni, A. R., Taranto, G., Losavio, F. P., Pignone, D. (2006): Common bean (Phaseolus vulgari.) landraces from Abruzzo and Lazio regions (Central Italy). - Genetic Resources and Crop Evolution 53(2): 313-322.

[36] Rohlf, F. J. (2000): NTSYS-pc, Numerical Taxonomy and Multivariate Analysis System, Version 2.1. - Exeter Software, New York. 
[37] Sarikamis, G., Yasar, F., Bakir, M., Kazan, K., Ergul, A. (2009): Genetic characterization of green bean (Phaseolus vulgaris) genotypes from eastern Turkey. - Genetics and Molecular Research 8(3): 880-887.

[38] Skroch, P., Nienhuis, J. (1995): Qualitative and quantitative characterization of RAPD variation among snap bean (Phaseolus vulgaris) genotypes. - Theoretical and Applied Genetics 91(6-7): 1078-1085.

[39] Sneath, P. H. A., Sokal, R. R. (1973): Numerical Taxonomy: The Principles and Practice of Numerical Classification. - WH Freeman, San Francisco, pp. 573.

[40] Tautz, D., Renz, M. (1984): Simple sequences are ubiquitous repetitive components of eukaryotic genomes. - Nucleic Acids Research 12: 4127-4138.

[41] TÜIK (2017): Turkish Statistical Institute data base. - Access date: 20/02/2018.

[42] Ulukapı, K., Onus, A. N. (2013): Selekte Edilmiş Bazı Yerel Taze Fasulye (Phaseolus vulgaris L.) Genotiplerinin Moleküler Karakterizasyonu. - Tarım Bilimleri Dergisi 18: 277-286.

[43] Velasquez, V. L. B., Gepts, P. (1994): RFLP diversity of common bean (Phaseolus vulgaris) in its centres of origin. - Genome 37(2): 256-263.

[44] Yu, K., Park, S., Poysa, V., Gepts, P. (2000): Integration of simple sequence repeat (SSR) markers into a molecular linkage map of common bean (Phaseolus vulgaris L.). - Journal of Heredity 91(6): 429-434.

[45] Zeven, A. C. (1998): Landraces: a review of definitions and classifications. - Euphytica 104: 127-139. 